\title{
Temporal variations of groundwater tables and implications for submarine groundwater discharge: a 3-decade case study in central Japan
}

\author{
Bing Zhang ${ }^{1,2,3}$, Jing Zhang ${ }^{2,1}$, and Takafumi Yoshida ${ }^{1}$ \\ ${ }^{1}$ Northwest Pacific Region Environmental Cooperation Center, 930-0856, Toyama, Japan \\ ${ }^{2}$ Earth and Environmental System, Graduate School of Science and Engineering, University of Toyama, 930-8555, \\ Toyama, Japan \\ ${ }^{3}$ Tianjin Key Laboratory of Water Resources and Environment, Tianjin Normal University, 300387, Tianjin, China
}

Correspondence to: Jing Zhang (jzhang@sci.u-toyama.ac.jp)

Received: 12 March 2017 - Discussion started: 14 March 2017

Revised: 6 June 2017 - Accepted: 6 June 2017 - Published: 11 July 2017

\begin{abstract}
Fresh submarine groundwater discharge (SGD) is the key pathway of flux and nutrients for the groundwater from land to the ocean. SGD flux is a current issue of discussion and a means to clarify the coastal marine system under climate change. SGD flux accounts for about one-quarter of the river runoff in the Katakai alluvial fan in Uozu, Toyama, Japan, which is an ideal area to study SGD flux considering the need for a rapid response to climate change and the prior research on SGD there. In this paper, the monthly groundwater table's condition over 30 years is analyzed using monthly rainfall, snowfall, and the climate change index. Rainfall has been on an upward trend, but the snowfall has decreased over 40 years. Furthermore, the groundwater table at monitoring wells in the coastal area increased, as a result of the increased rainfall. However, the relationship between snowfall and groundwater is negative. As expected by Darcy's law, SGD flux was controlled by the hydraulic gradient of the coastal groundwater. The estimated historic SGD flux by groundwater table variation shows an upward trend of SGD. Considering the increase in precipitation and the groundwater table, SGD flux may increase under climate change.
\end{abstract}

\section{Introduction}

Fresh submarine groundwater discharge (SGD) is the direct flow of groundwater into the ocean. The groundwater flows down a gradient, and SGD occurs wherever a coastal aquifer is connected to the sea (Chen et al., 2005; Zhang and Mandal, 2012). SGD has been recognized as not only an important source of freshwater discharge into the ocean, but also a valuable component of the hydrological cycle between the terrestrial groundwater system and the marine environment (Church, 1996; Taniguchi et al., 2002; Hatta and Zhang, 2013; Liu et al., 2014). The estimation of global SGD varies from 0.2 to $10 \%$ of the river flow (Burnnet et al., 2001). SGD may be both volumetrically and chemically important to coastal water and chemical budgets (Taniguchi et al., 2002). Thus, an accurate estimate of SGD flux is essential to predict future coastal environments under climate change conditions.

Toyama Bay is an ideal site to study SGD because it is easily accessible and has been studied in previous reports on several SGD sites off the coastal area (Fujii et al., 1986; Zhang and Satake, 2003; Nakaguchi et al., 2005; Hatta and Zhang, 2013). The SGD flow rates in the Katakai alluvial fan ( $\sim 680 \mathrm{~m} \mathrm{yr}^{-1}$; Zhang et al., 2005) are greater than most of those reported worldwide ( $\sim 454 \mathrm{~m} \mathrm{yr}^{-1}$; Taniguchi et al., 2002). The seepage water collected off Uozu is the potential type, which is the flow of the groundwater controlled by the potential of the spring in terms of conversion points of the geomorphologic gradient (Zhang and Satake, 2003). The 


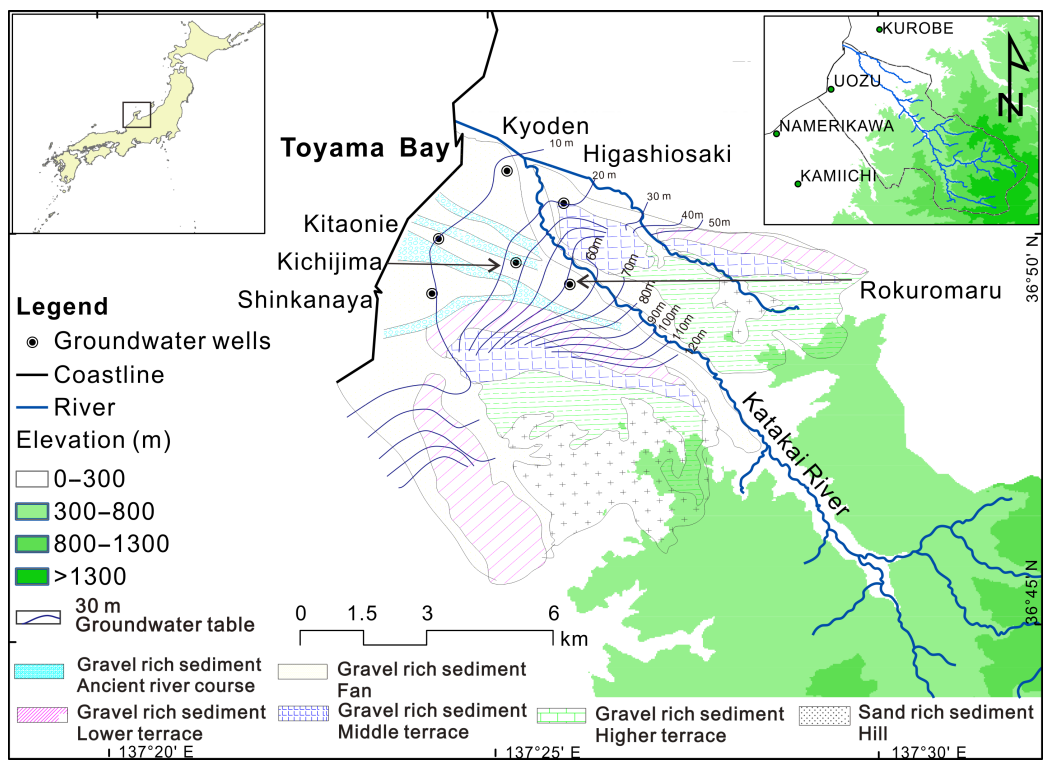

Figure 1. Locations of groundwater wells in the Katakai River alluvial fan.

source of the freshwater is the precipitation in the Toyama region. Furthermore, this area has shown a rapid response to climate change, with a recent reduction in the year-round snow extent on the top of nearby mountains, which is shown here to affect SGD flux into the coastal environment (Hatta and Zhang, 2013).

Groundwater is the linkage between precipitation and SGD. In this paper, we describe the temporal variations in the monthly groundwater table, rainfall, and snow from 1985 to 2015. Furthermore, we analyzed the relationship between rainfall, snowfall, and El Niño and La Niña events. The relation between SGD flux and the groundwater table was also studied. Finally, we discuss the impact of climate change on rainfall, the coastal groundwater system, and SGD.

\section{Study area}

\subsection{Study site description}

Toyama Bay, a semi-enclosed bay in central Japan, connects to the Sea of Japan at its northern boundary. There is buried forest and submarine groundwater seepage off Uozu, on the eastern side of Toyama Bay (Zhang and Satake, 2003). The Katakai River alluvial fan is located at Uozu, Toyama prefecture (Fig. 1). The SGD area of the Katakai River alluvial fan occurs 150-200 m seaward of the coastline at water depths of 8 and $22 \mathrm{~m}$. The average fluxes were $0.8-1.3 \mathrm{~L} \mathrm{~min}^{-1} \mathrm{~m}^{-2}$ at $8 \mathrm{~m}$ and $0.5-0.8 \mathrm{~L} \mathrm{~min}^{-1} \mathrm{~m}^{-2}$ at $22 \mathrm{~m}$ from April to December 2003 (Zhang et al., 2005).

The Katakai River alluvial fan is a coastal well-watered fan into which the Katakai River is deposited. The total area of the Katakai River catchment is $169 \mathrm{~km}^{2}$. The length of the main river is $27 \mathrm{~km}$ from the water source in the Kekachi Mountains ( $2414 \mathrm{~m}$ ). The average slope of the Katakai River bed is $8.5 \%$, which is the most steeply sloped river of the seven rivers in Japan. The average flux of the Katakai River is $10.2 \mathrm{~m}^{3} \mathrm{~s}^{-1}$. Annual precipitation is $2500 \mathrm{~mm}$ in Uozu, and it is about $4000 \mathrm{~mm}$ in the mountainous area. The annual average temperature is $14{ }^{\circ} \mathrm{C}$. The annual potential evapotranspiration is $765 \mathrm{~mm}$.

\subsection{Hydrogeology setting}

The groundwater head at the top of the alluvial fan is about $120 \mathrm{~m}$ (Fig. 1). The groundwater head gradient is high, due to the slope topography. The aquifer of the Katakai River fan is gravel and sand sediments. There are four ancient river courses in the central fan. The hydrogeological setting of Uozu consists of three layers. Layer A (top layer) is alluvium at the Holocene, consisting of gravel, sand, and clay layers. The thickness of layer A from the hill area to the coastal fan area is from 20 to about $100 \mathrm{~m}$, respectively. Layer B (middle layer) is the deposit of the dissected fan at the late and middle Pleistocene, including gravel, sand, and clay layers. The thickness of layer B in the fan area is about $80 \mathrm{~m}$. Layer C (bottom layer) is the deposit of the dissected fan at the early Pleistocene. The bedrock is sandstone and mudstone (Kokusai Kogyo Co. Ltd., 2002). There are artesian wells along the coastal area, due to the existence of clay layers in the sand aquifer. 
Table 1. Description of groundwater monitoring wells.

\begin{tabular}{llrrlrl}
\hline No. & Well & $\begin{array}{r}\text { Depth } \\
\mathrm{m}\end{array}$ & $\begin{array}{r}\text { Screen } \\
\text { depth } \\
\mathrm{m}-\mathrm{m}\end{array}$ & $\begin{array}{l}\text { Data } \\
\text { period } \\
\text { (years })\end{array}$ & $\begin{array}{r}\text { Groundwater } \\
\text { table }(\text { mean } \pm \text { SD) } \\
\mathrm{m}\end{array}$ & $\begin{array}{l}\text { Linear regression* } \\
\end{array}$ \\
\hline 1 & Shinkanaya & 100 & $72-94$ & $1985-2015$ & $9.71 \pm 0.75$ & $y=0.01 x-4.75(p=0.12)$ \\
2 & Shinkanaya & 33 & $17-28$ & $1985-2015$ & $9.69 \pm 0.77$ & $y=0.12 x-14.99(p<0.01)$ \\
3 & Kichijima & 80 & $25-36$ & $1985-2015$ & $24.96 \pm 2.44$ & $y=-0.07 x+171.88(p<0.01)$ \\
4 & Higashiosaki & 42.5 & $9-20$ & $1985-2015$ & $19.77 \pm 1.32$ & $y=0.04 x-63.77(p<0.01)$ \\
5 & Kyoden & 100 & $56-67,78-89$ & $1985-2015$ & $9.86 \pm 0.38$ & $y=0.01 x-7.30(p<0.01)$ \\
6 & Rokuromaru & 38 & $27-33$ & $2004-2015$ & $42.72 \pm 4.08$ & $y=0.41 x-780.20(p<0.01)$ \\
7 & Rokuromaru & 80 & $64-75$ & $2004-2015$ & $40.96 \pm 4.01$ & $y=0.36 x-683.24(p<0.01)$ \\
8 & Kitaonie & 70 & $59-71$ & $2002-2015$ & $6.83 \pm 0.49$ & $y=0.04 x-76.76(p<0.01)$ \\
\hline
\end{tabular}

* Linear regression between groundwater table $(y)$ and month $(x)$.

\section{Methods}

\subsection{Data source}

The groundwater table monitoring data (from 1985 to 2015) were obtained from the Water Information Database, Uozu, Toyama Prefecture, Japan. The precipitation data (from 1976 to 2015) and historical El Niño/La Niña events were obtained from the website of the Japan Meteorological Agency (http: //www.jma.go.jp/jma/index.html). The Oceanic Niño Index (ONI) was from the Center for Weather and Climate Prediction (CPC), National Oceanic and Atmospheric Administration (NOAA), U.S. Department of Commerce. The ONI values are calculated by the monthly Niño 3.4 index. The statistical characteristics and linear regression of the monthly groundwater table, rainfall and snowfall were analyzed by SPSS software.

\subsection{Analytical methods}

Wavelet transforms are a very powerful tool in which to analyze non-stationary signals. It allows for the identification of the main periodicity in a time series and the evolution at the time of each frequency (Liang et al., 2011). The cross wavelet transform is used to examine relationships in time frequency space between two time series (Labat, 2010). Phase angle statistics can be used to gain confidence in causal relationships between the time series (Grinsted et al., 2004; Zhang and Wang, 2016).

The methods of continuous wavelet transform (CWT) and cross wavelet transform (XWT) provide the basis for wavelet coherence analysis (Grinsted et al., 2004). The wavelet coherence (WTC) of two time series was defined as

$R_{n}^{2}(s)=\frac{\left|S\left(s^{-1} W_{n}^{X Y}(s)\right)\right|^{2}}{S\left(s^{-1}\left|W_{n}^{X}(s)\right|^{2}\right) \cdot S\left(s^{-1}\left|W_{n}^{Y}(s)\right|^{2}\right)}$,

where $S$ is a smoothing operator. The wavelet coherence is a localized correlation coefficient in time frequency space
(Grinsted et al., 2004). The arrows $\rightarrow$ and $\leftarrow$ in the WTC figures indicate the positive and negative relationships between two time series, respectively. Meanwhile, the arrows $\downarrow$ and $\uparrow$ show that time series 1 is a one-quarter period earlier and later, respectively, than time series 2 (Zhang and Wang, 2016).

\section{Results}

\subsection{Groundwater table variation}

There are six groundwater monitoring sites, including eight monitoring wells in the Katakai River alluvial fan (Table 1). The average groundwater table decreased from the mountain area to the coastal plain area; the groundwater table of Rokuromaru is the highest, with average values of 42.72 and $40.96 \mathrm{~m}$, respectively. The groundwater of Kichijima $(24.96 \mathrm{~m})$ is the second highest, followed by that of Higashiosaki $(19.77 \mathrm{~m})$. The groundwater tables of Shinkanaya and Kyoden are about $10 \mathrm{~m}$. The groundwater level of Kitaonie, which is the nearest to Toyama Bay, is the lowest $(6.83 \mathrm{~m})$. The range variations of Rokuromaru and Kichijima are the largest, while that of Kyoden is the smallest. The standard deviation of shallow groundwater is larger than the deep groundwater at the same site.

The groundwater table trends of the monitoring wells are similar (Fig. 2). Linear regression was applied to analyze the trends of the groundwater variation. The standardized coefficients of most groundwater wells are significantly positive, indicating an increase in groundwater table (Table 1). However, the groundwater table of Kichijima may decline, since the standardized coefficient is significantly negative.

\subsection{Rainfall and snowfall variations}

The average rainfall and snowfall in Uozu were $2473 \mathrm{~mm}$ and $385 \mathrm{~cm}$, respectively, from 1976 to 2015 (Table 2). However, rainfall increased while snowfall decreased during these years. Rain increased by $14.76 \%$ and snowfall 

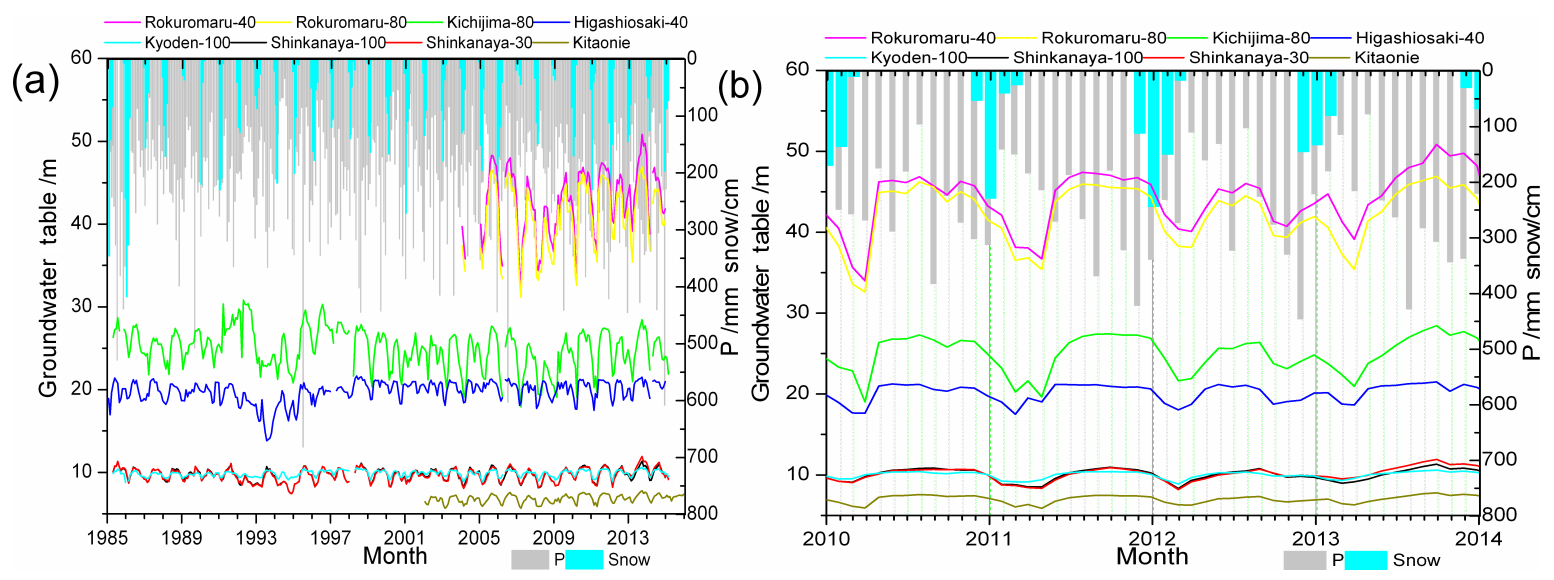

Figure 2. Monthly groundwater table, rainfall, and snowfall from 1985 to 2014 (a), and from 2010 to 2014 (b).

Table 2. Description and prediction of rainfall, snow, and the water budget.

\begin{tabular}{|c|c|c|c|c|c|c|c|}
\hline & \multicolumn{2}{|c|}{$\begin{array}{l}\text { Average (mean } \pm \text { SD) } \\
\mathrm{mm} \mathrm{yr}^{-1}\end{array}$} & \multicolumn{5}{|c|}{$\begin{array}{l}\text { Water budget* } \\
10^{7} \mathrm{~m}^{3} \mathrm{yr}^{-1}\end{array}$} \\
\hline & Rainfall & Snowfall & Precipitation & Evapotranspiration & River runoff & Groundwater usages & SGD \\
\hline 1976-1996 & $2311 \pm 616$ & $4492 \pm 2629$ & $47 \pm 13$ & $11 \pm 2.9$ & $28 \pm 7.5$ & $2.0 \pm 0.5$ & $6.0 \pm 1.6$ \\
\hline 1997-2015 & $2652 \pm 300$ & $3282 \pm 1346$ & $54 \pm 6.1$ & $13 \pm 1.5$ & $32 \pm 3.6$ & $2.0 \pm 0.2$ & $6.0 \pm 0.68$ \\
\hline 1976-2015 & $2473 \pm 516$ & $3850 \pm 2110$ & $50 \pm 10$ & $12 \pm 2.5$ & $30 \pm 6.3$ & $2.0 \pm 0.4$ & $6.0 \pm 1.2$ \\
\hline 2010-2030 & $2949 \pm 150$ & $2573 \pm 987$ & $60 \pm 3.1$ & $14 \pm 0.73$ & $36 \pm 1.8$ & $2.4 \pm 0.1$ & $7.2 \pm 0.37$ \\
\hline 2030-2050 & $3147 \pm 695$ & $970 \pm 387$ & $64 \pm 14$ & $15 \pm 3.4$ & $38 \pm 8.5$ & $2.6 \pm 0.6$ & $7.7 \pm 1.7$ \\
\hline
\end{tabular}

* Water budget is calculated by percentage of evapotranspiration ( $24 \%$ ), river runoff $(60 \%)$, groundwater usages ( $4 \%$ ), and submarine groundwater discharge (SGD, $12 \%)$ to precipitation from 1976 to 2015 in Uozu.

decreased by $26.94 \%$ over the past 20 years, compared to the 20 years from 1976 to 1996 . The linear regression of annual rainfall is $y=18.322 x-34088.74(p<0.01)$, indicating increased rainfall in the future. However, the annual snowfall amount decreased, with a linear regression of $y=-6.712 x+13792.71(p<0.05)$. Furthermore, the percentage of snow in total precipitation was $19.44 \%$ from 1976 to 1996 , and this declined to $12.38 \%$ from 1997 to 2015 .

\subsection{Relationship between rainfall, snowfall, and groundwater}

The groundwater table in summer (June to August) is the highest, while the groundwater table in early spring (March to May) is the lowest (Fig. 2a, b). The groundwater table declined sharply during winter, especially after snowfall. The groundwater table is the lowest 1 or 2 months after the end of snowfall. Comparing the peaks of rainfall and the groundwater table, the rainfall in August 2010 was the largest, and the highest groundwater table occurred 2 months later. The groundwater table also increased to its peak 2 months after the peak rainfall in December 2012 and August 2013 (Fig. 2b).
The relationships among rainfall, snowfall, and groundwater table were analyzed by wavelet coherence. Taking the Shinkanaya $(30 \mathrm{~m})$ monitoring well as an example, the relationship between groundwater table and rainfall was positive from 1990 to 2010, with a period of 2-4 years (Fig. 3a), while the groundwater lagged behind by about a quarter year from 1985 to 1995,1998 to 2002 , and 2003 to 2015, with a 1 -year period. However, the groundwater table is negatively correlated with snowfall from 1985 to 2015, with a 1-year period (Fig. 3b). This result coincides with that in Fig. 2b. The groundwater table decreased when snowfall began in winter.

\subsection{Relationships among rainfall, snowfall, and climate change index}

Wavelet coherence was used to analyze the relationships among rainfall, snowfall, and climate change index (ONI). The relationship between rainfall and ONI is significantly negative in 1- and 3-5-year periods (Fig. 3c), indicating that the La Niña events may increase rainfall. The climate change index was about a quarter year earlier than snowfall beginning in a 0.5 -year period (Fig. 3d). The climate change index, associated with El Niño and La Niña events, significantly influences rainfall and snowfall. 

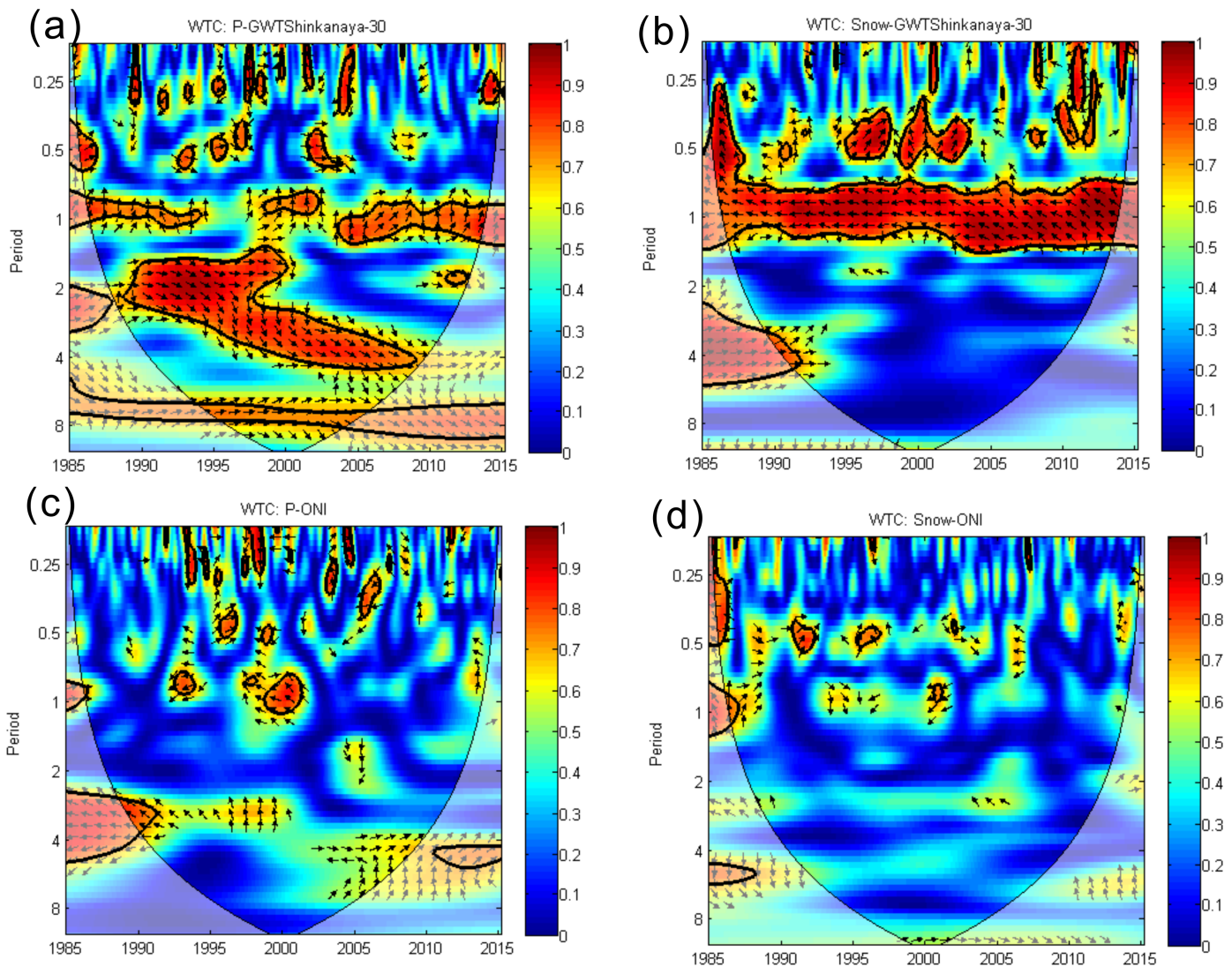

Figure 3. Squared wavelet coherence between rainfall and groundwater table (a), snowfall and groundwater table (b), rainfall and the ONI (c), and snowfall and the ONI (d).

For the analysis of the relationship between climate change and rainfall, snowfall is the basis used to determine the impact of climate change on groundwater. We used the Oceanic Niño Index (ONI) to estimate the climate changes associated with the El Niño and La Niña events.

There were six El Niño and six La Niña events from 1985 to 2015 (Fig. 4). The seasonal rainfall and snowfall during El Niño events were $642 \mathrm{~mm}$ and $155 \mathrm{~cm}$, and those during La Niña events were $635 \mathrm{~mm}$ and $157 \mathrm{~cm}$, respectively. The ratios of snowfall and rainfall during El Niño and La Niña events were 1.17 and 1.39, respectively. The most extreme El Niño event was from spring 1997 to spring $1998(\mathrm{ONI}=2.3)$. The most extreme La Niña events occurred during spring 1988 to spring 1989 (ONI $=-1.7)$. The La Niña events may have caused more snowfall and more extreme monthly snowfall than El Niño.

\subsection{Relationship between groundwater and SGD}

The submarine groundwater discharge off Uozu is controlled by the potential of the geomorphologic gradient (Zhang and Satake, 2003). Darcy's law describes the water flow through a porous medium (sand). The groundwater aquifer in Uozu is sand. Thus, according to Darcy's law, the groundwater flow rate is correlated with the hydraulic gradient (Mulligan and Charette, 2006). The SGD flux is positive for the groundwater table. Using the monitoring SGD flux over April to August 2003 (Zhang et al., 2005), we established the relationship between monthly SGD flux $\left(y, \mathrm{~m} \mathrm{month}^{-1}\right)$ and groundwater variation $\left(x, \mathrm{~m} \mathrm{month}^{-1}\right)$.

Here, $x$ is the summarized daily groundwater table variation (daily groundwater table above $5.5 \mathrm{~m}$ ).

For SGD flux at $8 \mathrm{~m}, y=0.45 x+25.28 .\left(R^{2}=0.819\right)$

For SGD flux at $22 \mathrm{~m}, y=0.65 x-2.53\left(R^{2}=0.819\right)$.

The monthly SGD flux may be estimated according to the monthly groundwater table variation. Then, the annual SGD flux can be calculated based on the monthly SGD flux. The estimated SGD flux off the Katakai River alluvial fan is shown in Fig. 5. The estimated data show that the SGD flux is dominated by the groundwater table variation. Furthermore, SGD flux increased as a consequence of the groundwater table increasing. The SGD flux we estimated is 8 and $22 \mathrm{~m}$ off Uozu. However, the fresh SGD flux at $40-100 \mathrm{~m}$ is about 2 to 4 times 0-40 m (Hatta and Zhang, 2013). Compared to the results of the water budget (Table 2), the fresh SGD may be underestimated. However, since the groundwater table is 


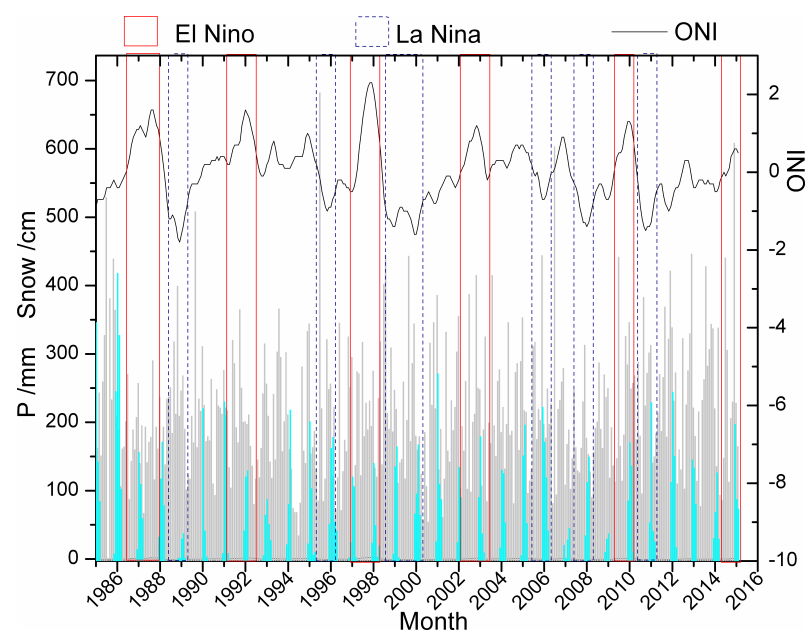

Figure 4. Rainfall (P), snowfall (Snow), Oceanic Niño Index (ONI), and El Niño and La Niña events.

easy to determine, the fresh SGD flux could be estimated by Eqs. (2) and (3) in the coastal sand aquifer.

\section{Discussion}

\subsection{Impact of climate change on rainfall}

The annual precipitation at Uozu, Toyama prefecture, is about $2500 \mathrm{~mm}$, and it is in an increasing trend. The precipitation is 1.52 times the mean precipitation $(1634 \mathrm{~mm})$ in Japan (Xu et al., 2003). This high precipitation is caused by high seawater temperature, which is maintained by the warm Tsushima current moving at 2.6 million $\mathrm{m}^{3} \mathrm{~s}^{-1}$ from the southwest to the northeast along the Japan Sea coast (Zhang and Satake, 2003). The cold northwesterly wind gathers much water vapor from the Sea of Japan, bringing heavy snow to the Sea of Japan side (Kawase et al., 2013). Furthermore, the precipitation patterns are dominated by shifts as sea-surface temperatures change, e.g., El Niño and La Niña (Trenberth, 2011). Climate change, with warming conditions and increased moisture, may produce more intense precipitation events. More precipitation occurs as rain instead of snow, and snow melts earlier (Emori, 2005; Trenberth, 2011; Fischer and Knutti, 2015). The impact of climate change on precipitation is changing the precipitation amount and type, causing an increase in precipitation (about 0.1 to $24.5 \mathrm{~mm} \mathrm{decade}^{-1}$ ) (Wang et al., 2017) and a decrease in snow at Toyama. The annual precipitation may increase to about $3000 \mathrm{~mm}$ by 2030; and annual snowfall will decrease to less than $1000 \mathrm{~mm}$ by 2050 (Table 2). Moreover, the El Niño and La Niña events influence regional anomalous circulation features (Leung et al., 2017) and the frequency of extreme precipitation.

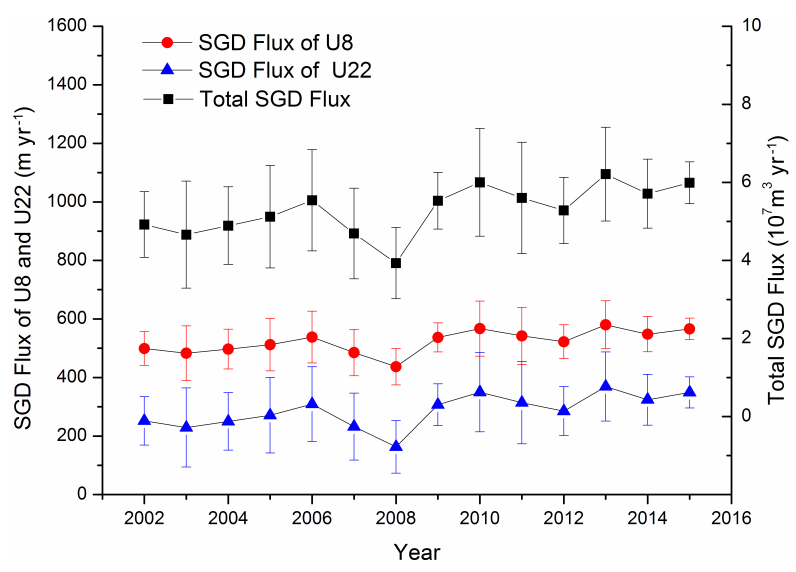

Figure 5. Estimated SGD flux by groundwater table.

\subsection{Implication for coastal groundwater systems}

The groundwater table variation is not only determined by precipitation, but also by human activities. The utilization of snowmelt for groundwater may cause the lowest groundwater table in winter at Uozu (Kokusai Kogyo Co. Ltd., 2002). Moreover, climate change in combination with increased anthropogenic activities will affect coastal groundwater systems (Oude Essink et al., 2010). In a warmer world, less winter precipitation falls as snow, and the melting of winter snow occurs earlier in spring. Meanwhile, much of the winter runoff will immediately be lost to the oceans (Barnett et al., 2005). Furthermore, the groundwater extraction may cause groundwater depletion. The contribution of groundwater depletion to global sea-level rise amounted to $0.27 \mathrm{~mm} \mathrm{yr}^{-1}$ in 2000 (Wada et al., 2016). The impact of groundwater extraction on coastal aquifers was more significant than the impact of sea-level rise on groundwater recharge (Ferguson and Gleeson, 2012). Due to the increased precipitation, the groundwater recharge amount increased in Uozu. With snowfall decreasing, the portion of groundwater provided by snowmelt may decline. Furthermore, the El Niño and La Niña events change the groundwater table pattern. The El Niño events increase the groundwater table in winter, while the La Niña events increase the groundwater table sharply in summer (Fig. 2). Under climate change and the influence of human activities (Han et al., 2016), the groundwater table may increase with an irregular pattern in the future.

\subsection{Implication for submarine groundwater discharge}

According to the terrestrial water budget, an estimated $33 \times$ $10^{8} \mathrm{~m}^{3} \mathrm{yr}^{-1}$ of groundwater discharged from the continental shelf into Toyama Bay as fresh submarine groundwater discharge (Ito and Fuji, 1993; Zhang and Satake, 2003). The estimated submarine groundwater discharge is approximately $6 \times 10^{7} \mathrm{~m}^{3} \mathrm{yr}^{-1}$, which is $20 \%$ of the river's outflow $\left(30 \times 10^{7} \mathrm{~m}^{3} \mathrm{yr}^{-1}\right)$ in Uozu (Kokusai Kogyo Co. Ltd., 
2002) (Table 2). However, the precipitation varies under climate change, because the ratio of rainfall and snow would increase. Furthermore, the variations of meteorological parameters, e.g., temperature and humidity, may cause the changes in evapotranspiration (Cong et al., 2009; Shimizu et al., 2015), as well as river runoff and groundwater discharge in the water budget. Thus, the uncertainty of percentage of evapotranspiration, river runoff, and groundwater discharge in the total water budget may exist.

SGD is one of the indicators that reflect the effects of climate change on the marine ecosystem. It has been reported that the SGD-sea level correlation was high (Taniguchi and Iwakawa, 2004). However, the increased head in the groundwater system at the coast can be easily produced, due to the highly permeable Holocene and Pleistocene layers (Kokusai Kogyo Co. Ltd., 2002; Oude Essink et al., 2010). The average concentration of $\mathrm{NO}_{3}^{-}$in fresh SGD $\left(0.69 \mathrm{mg} \mathrm{L}^{-1}\right)$ is larger than riverine input $\left(0.18 \mathrm{mg} \mathrm{L}^{-1}\right)$ (Hatta and Zhang, 2013). The estimated SGD flux is described in Table 2 and Fig. 5. The SGD flux increases over 3 decades; the dissolved inorganic nitrogen (DIN) flux in the SGD to Toyama Bay may increase. Thus, the submarine groundwater discharge is a significant source of nutrition, more than river water, to the coastal marine ecosystem of Toyama Bay (Zhang and Satake, 2003; Lee et al., 2010).

Moreover, SGD flux may affect the availability of planktonic food for fish larvae. Fish production appears to be controlled by the climatic factors governing the processes in upwelling systems (Walther et al., 2002). Due to the increased precipitation and groundwater table, SGD flux may increase under climate change in the future. However, the annual SGD flux may be around $7 \times 10^{7}$ and $8 \times 10^{7} \mathrm{~m}^{3}$ by 2030 and 2050 , respectively (Table 2), as a result of the increase in the groundwater table (Table 3). The increased amount of SGD is less than river runoff, since most increased precipitation changes into river runoff to the ocean.

\section{Conclusions}

Groundwater table, rainfall, and snowfall datasets from 1985 to 2015 were collected to analyze their variations. The relationships among groundwater table, rainfall, snow, and climate change events were analyzed by wavelet coherence to discuss the implications for climate change. The results are summarized as follows.

1. The groundwater table is the highest in summer and the lowest in spring. The average groundwater table decreased from the mountainous area to the coastal plain area. Linear regression reflected the increase in the groundwater table in almost all monitoring wells. Rainfall increased and snowfall declined over 40 years.

2. The relationship between the groundwater table and rainfall is positive. The groundwater tables increased to the peak 1 to 2 months after the peak rainfall. The groundwater table is negatively correlated with snowfall. The climate change index associated with El Niño and La Niña events, especially La Niña, may cause extreme rainfall and snowfall.

3. SGD flux was controlled by the hydraulic gradient of the coastal groundwater. The linear regression between SGD flux and the groundwater table was established. The historic SGD flux was estimated by groundwater table variation. The upward trend of the precipitation and groundwater table may indicate an increase in SGD flux, although with some uncertainty.

This study demonstrates that groundwater is the linkage between climate change and submarine groundwater discharge with long time datasets. Due to increases in precipitation and the groundwater table, the flux of submarine groundwater discharge will increase under climate change. In addition, the quality of submarine groundwater discharge should be clarified under climate change conditions worldwide in the future.

Data availability. The groundwater table data are available in the Annual Groundwater Report (http://www.pref.toyama. jp/cms_sec/1706/kj00000960.html, last access: 3 July 2017). The Oceanic Niño Index (ONI) is shown on the website (http://www.cpc.ncep.noaa.gov/products/analysis_monitoring/ ensostuff/ensoyears.shtml, last access: 3 July 2017). The detailed data source is explained in Sect. 3.1.

Competing interests. The authors declare that they have no conflict of interest.

Acknowledgements. This research was supported by the Grant-inAid for Scientific Research on Innovative Areas grant (25110505 and 15H00973), the JSPS KAKENHI grants (JP26241009), and the Environment Research and Technology Development Fund (S-13) of the Ministry of the Environment, Japan.

Edited by: Ying Fan

Reviewed by: two anonymous referees

\section{References}

Barnett, T. P., Adam, J. C., and Lettenmaier, D. P.: Potential impacts of a warming climate on water availability in snow-dominated regions, Nature, 438, 303-309, https://doi.org/10.1038/nature04141, 2005.

Burnnet, W. C., Taniguchi, M., and Oberdorfer, J.: Measurement and significance of the direct discharge of groundwater into the coastal zone, J. Sea Res., 46, 109-116, https://doi.org/10.1016/S1385-1101(01)00075-2, 2001. 
Chen, C.-T. A., Zhang, J., Peng, T.-R., and Hagiwara, T.: Exploratory Sampling of Submarine Groundwater Discharge in Taiwan, Chikyukagaku(Geochemistry), 39, 165-171, 2005.

Church, C. M.: An underground route for the water cycle, Nature, 380, 579-580, https://doi.org/10.1038/380579a0, 1996.

Cong, Z. T., Yang, D. W., and Ni, G. H.: Does evaporation paradox exist in China?, Hydrol. Earth Syst. Sci., 13, 357-366, https://doi.org/10.5194/hess-13-357-2009, 2009.

Emori, S.: Dynamic and thermodynamic changes in mean and extreme precipitation under changed climate, Geophys. Res. Lett., 32, L17706, https://doi.org/10.1029/2005GL023272, 2005.

Ferguson, G. and Gleeson, T.: Vulnerability of coastal aquifers to groundwater use and climate change, Nature Climate Change, 2, 342-345, https://doi.org/10.1038/nclimate1413, 2012.

Fischer, E. M. and Knutti, R.: Anthropogenic contribution to global occurrence of heavy-precipitation and hightemperature extremes, Nature Clim. Change, 5, 560-564, https://doi.org/10.1038/nclimate2617, 2015.

Fujii, S., Nasu, N., Smith, A. J., Fuji, N., Mizutani, Y., Shimakura, M., Konishi, K., Igarashi, C., Muramoto, J., Takemura, T., Shimoda, T., Boggs, S., Jr., Fujioka, K., Mappa, H., Kawahata, H., Kong, Y. S., and Tanaka, T.: Submerged forest off Nyuzen, Kurobegawa alluvial fan, Toyama Bay, Central Japan, Boreas, 15, 265-277, https://doi.org/10.1111/j.15023885.1986.tb00931.x, 1986.

Grinsted, A., Moore, J. C., and Jevrejeva, S.: Application of the cross wavelet transform and wavelet coherence to geophysical time series, Nonlin. Processes Geophys., 11, 561-566, https://doi.org/10.5194/npg-11-561-2004, 2004.

Han, D., Song, X., and Currell, M. J.: Identification of anthropogenic and natural inputs of sulfate into a karstic coastal groundwater system in northeast China: evidence from major ions, $\delta^{13} \mathrm{C}_{\mathrm{DIC}}$ and $\delta^{34} \mathrm{~S}_{\mathrm{SO}_{4}}$, Hydrol. Earth Syst. Sci., 20, 19831999, https://doi.org/10.5194/hess-20-1983-2016, 2016.

Hatta, M. and Zhang, J.: Temporal changes and impacts of submarine fresh groundwater discharge to the coastal environment: A decadal case study in Toyama Bay, Japan, J. Geophys. Res.Oceans, 118, 2610-2622, https://doi.org/10.1002/jgrc.20184, 2013.

Ito, T. and Fuji, S.: Water budget of groundwater in Toyama basin, Mem. Toyama Geogr. Soc., 10, 3-14, 1993 (in Japanese).

Kawase, H., Hara, M., Yoshikane, T., Ishizaki, N. N., Uno, F., Hatsushika, H., and Kimura, F.: Altitude dependency of future snow cover changes over Central Japan evaluated by a regional climate model, J. Geophys. Res.-Atmos., 118, 12444-12457, https://doi.org/10.1002/2013JD020429, 2013.

Kokusai Kogyo Co. LTD: Report on the groundwater appropriate utilization in Uozu, Uozu, 2002.

Labat, D.: Cross wavelet analyses of annual continental freshwater discharge and selected climate indices, J. Hydrology, 385, 269278, https://doi.org/10.1016/j.jhydrol.2010.02.029, 2010.

Lee, Y.-W., Kim, G., Lim, W.-A., and Hwang, D.-W.: A relationship between submarine groundwater borne nutrients traced by $\mathrm{Ra}$ isotopes and the intensity of dinoflagellate red-tides occurring in the southern sea of Korea, Limnol. Oceanogr., 55, 1-10, https://doi.org/10.4319/lo.2010.55.1.0001, 2010.

Leung, M. Y.-T., Cheung, H. H. N., and Zhou, W.: Meridional displacement of the East Asian trough and its re- sponse to the ENSO forcing, Clim. Dynam., 48, 335-352, https://doi.org/10.1007/s00382-016-3077-8, 2017.

Liang, L., Li, L., and Liu, Q.: Precipitation variability in Northeast China from 1961 to 2008, J. Hydrol., 404, 67-76, https://doi.org/10.1016/j.jhydrol.2011.04.020, 2011.

Liu, Q., Charette, M. A., Henderson, P. B., McCorkle, D. C., Martin, W., and Dai, M.: Effect of submarine groundwater discharge on the coastal ocean inorganic carbon cycle, Limnol. Oceanogr., 59, 1529-1554, https://doi.org/10.4319/lo.2014.59.5.1529, 2014.

Mulligan, A. E. and Charette, M. A.: Intercomparison of submarine groundwater discharge estimates from a sandy unconfined aquifer, J. Hydrol., 327, 411-425, https://doi.org/10.1016/j.jhydrol.2005.11.056, 2006.

Nakaguchi, Y., Yamaguchi, Y., Yamada, H., Zhang, J., Suzuki, M., Koyama, Y., and Hayashi, K.: Characterization and origin of chemical components in the submarine groundwater discharge in Toyama Bay, Geochemistry, 39, 119-130, 2005 (in Japanese with English abstract).

Oude Essink, G. H. P., van Baaren, E. S., and de Louw, P. G. B.: Effects of climate change on coastal groundwater systems: A modeling study in the Netherlands, Water Resour. Res., 46, W00F04, https://doi.org/10.1029/2009WR008719, 2010.

Shimizu, T., Kumagai, T. O., Kobayashi, M., Tamai, K., Iida, S. I., Kabeya, N., Ikawa, R., Tateishi, M., Miyazawa, Y., and Shimizu, A.: Estimation of annual forest evapotranspiration from a coniferous plantation watershed in Japan (2): Comparison of eddy covariance, water budget and sap-flow plus interception loss, J. Hydrol., 522, 250-264, 2015.

Taniguchi, M. and Iwakawa, H.: Submarine groundwater discharge in Osaka Bay, Japan, Limnology, 5, 25-32, https://doi.org/10.1007/s10201-003-0112-3, 2004.

Taniguchi, M., Burnett, W. C., Cable, J. E., and Turner, J. V.: Investigation of submarine groundwater discharge, Hydrol. Process., 16, 2115-2129, https://doi.org/10.1002/hyp.1145, 2002.

Trenberth, K. E.: Changes in precipitation with climate change, Clim. Res., 47, 123-138, https://doi.org/10.3354/cr00953, 2011.

Wada, Y., Lo, M.-H., Yeh, P. J. F., Reager, J. T., Famiglietti, J. S., Wu, R.-J., and Tseng, Y.-H.: Fate of water pumped from underground and contributions to sea-level rise, Nature Clim. Change, 6, 777-780, https://doi.org/10.1038/nclimate3001, 2016.

Walther, G.-R., Post, E., Convey, P., Menzel, A., Parmesan, C., Beebee, T. J. C., Fromentin, J.-M., Hoegh-Guldberg, O., and Bairlein, F.: Ecological responses to recent climate change, Nature, 416, 389-395, 2002.

Wang, L., Wu, Z., He, H., Wang, F., Du, H., and Zong, S.: Changes in summer extreme precipitation in Northeast Asia and their relationships with the East Asian summer monsoon during 1961-2009, Int. J. Climatol., 37, 25-35, https://doi.org/10.1002/joc.4683, 2017.

$\mathrm{Xu}, \mathrm{Z}$. X., Takeuchia, K., and Ishidaira, H.: Monotonic trend and step changes in Japanese precipitation, J. Hydrol., 279, 144-150, https://doi.org/10.1016/S0022-1694(03)00178-1, 2003.

Zhang, B. and Wang, Z.-L.: Trend and multi-time scale crosswavelet analysis on precipitation and temperature in Tianjin area Journal of Tianjin Normal University (Natural Science Edition), 36, 32-39, 2016 (in Chinese with English abstract).

Zhang, J. and Mandal, A. K.: Linkages between submarine groundwater systems and the environment, Current 
Opinion in Environmental Sustainability, 4, 219-226, https://doi.org/10.1016/j.cosust.2012.03.006, 2012.

Zhang, J. and Satake, H.: Chemical characteristics of submarine groundwater seepage in Toyama Bay, Central Japan, Land and Marine Hydrogeology, edited by: Taniguchi, M., Wang, K., and Gamo, T., Elsevier, Amsterdam, the Netherlands, 2003.
Zhang, J., Hagiwara, T., Koyama, Y., Satake, H., Nakamura, T., and Asai, K.: A new flow rate measuring method - SGD (submarine groundwater discharge) flux chamber and its approach off Katakai Alluvial Fan, Toyama Bay, Central Japan, Chikyukagaku(Geochemistry), 39, 141-148, 2005. 